\title{
遺跡の復元的考察を支援する知識システムの開発 \\ ON THE DEVELOPMENT OF KNOWLEDGE SYSTEM FOR SPATIAL ANALYSIS OF HISTORIC RUINS
}

\author{
中村裕文*, 両角光男**, 位寄和 久** \\ Hirofumi NAKAMURA, Mitsuo MOROZUMI and Kazuhisa IKI
}

\begin{abstract}
It is one of the difficult studies that needs broad knowledge and long experiences only specialists have to analyze the original shape of historic ruins. To support these studies, there are strong needs for a tool to share specialists' knowledge as well as to perform systematic inference. It is an objective of this paper to discuss a knowledge system the authors developed to support spatial analysis of excavated ruins. Taking an analysis on a plan of Islamic houses in Tunis as the case, the authors showed that computerized knowledge system that works with a high speed personal computer could support such work as described above.
\end{abstract}

Keywords : Knowledge system, Truth maintenance system, Spacial analysis of historic ruins, Isramic house 知識システム、真理保全機構、遺跡の復元的考察支援、イスラム住宅

\section{1. 研究の背景}

遺跡、遺構は過去において何らかの理由で放棄され時間の経過と共 に風化・埋没してしまうなど、完全な形状を保った状態で発見・調查 されることはほとんどない。また古建築なども建設当初の状態から改 築、增築を経てその構造、空間の利用形態が変更されていることが多 い。そのため遺跡、遺構の原形状や建設当初の空間利用形態などを推 定し復元する研究が行われてきた注】。その方法は、対象から得られ た直接的事実と、文献調査、あるいは類似した事例などから得られた 知識を参考に、研究者が仮定注 2)、推論を組み合わせて行う作業であ る。本論文ではこの復元の考察過程を復元的考察と呼ぶ。

このような遺跡、遺構、古建築の復元的考察の過程は、専門的な知 識を持った研究者が経験を基に手探りで行なっている現状である。そ の過程では個々の研究者が知識として蓄積した直接間接の情報が研究 の手がかりとなるものの、情報の蓄積と推論という点では次のような 障害があったように思われる。

（1）蓄積した情報を的確に記述する方法が確立していないため、個々 の研究者の持つ情報が適切に共有されにくい。

(2) 復元的考察について、システマティックな推論の方法が確立され ていないため、見過ごしや思い違いなど、折角の知識が生かされ にくい。

* 都城工業高等専門学校建築学科 助手·工修

** 熊本大学工学部環境システム工学科 教授・工博

\section{2. 研究の目的と方法}

本研究は、復元的考察を知識工学の技術を利用して支援する技術の 開発を目的とする。

復元的考察では大きく分けて次のような 2 種類の推論が行われる。 1) 直接的な推論

復元の対象となる部分の知識、直接的な事実から原形状を推定す る。出土した遺物や、生活の痕跡など直接的な証拠を基に建物各室の 用途を推定する方法がこれに該当する。

\section{2) 間接的な推論}

直接推定するのに情報が不足する場合、対象となる遺構の部分の復 元を仮定して全体の復元と矛盾のないことを確認し推定する。すなわ ち次の(1)〜(4)を繰返す。

(1) 断片的な情報や知識から対象となる部分の復元を仮定する。

(2) 仮定を復元対象の他の部分とつきあわせて全体的な復元に矛盾が ないか検証する。もし矛盾が見つからなければ、その仮定が正し いとして次の作業に移る。

(3) 作業の過程で新しく提案した復元の仮定と、先の仮定が矛盾を起 こしたとき、両者を検討し、より整合性の高い仮定を採用する。

(4) (3)の結果、古い仮定が否定されたとき、その仮定の成立を前提と Research Assoc., Dept. of Architecture, Miyakonojo National College of Technology, M. Eng. Prof., Dept. of Architecture, Faculty of Engineering, Kumamoto University, Dr. Eng. 
した仮定も否定されることとなり再度全体の仮定の検証を行う。 実際の復元的考察では直接的な推論と間接的な推論の方法が複雑に からみあって行われるため、推論の過程での論理矛盾の発見、ロジッ クの検証は物理的な困難さをともなう。

そこで、本研究ではコンピュータを利用して復元的考察を支援する ため、専門家の経験的知識（ヒューリスティクス）や、その他の知識 をコンピュータへ組み込み、人間に代わってあるいは人間をたすけて 問題解決を行う知識システムの考え方を利用する生 31 。またこうした 取組は、研究者の知識を外在化でき、多くの研究者の経験的知識を組 み合わせて利用することが可能になる。この方法により従来失われて いた、研究者相互の情報の交換による推論の可能性を得られるという 効果も期待できる。

本研究では復元的考察の範囲を建築物の平面構成、空間利用の復元 にしぼり、TMS（Truth Maintenance System : 真理保全機構）を 利用した復元支援システムのプロトタイプを試作し、システムを応用 した考察の可能性を検討する。具体的には(1)事実や知識のTMSによ る記述方法の検討、(2)推論エンジンの考え方、(3)作業手順を提案す る。事例としてチュニスのイスラム住宅をとりあげ、その平面形を手 がかりとしてイスラム住宅に関するルールやその他の知識を用いて平 面の各室の建設当時の利用形態を推論する。

\section{3. 知識システムの䕙築}

\section{1. システムの權成}

本研究では、復元的考察を支援するための推論方式として非単調推 論を用いる。単調推論では、復元的考察の様に互いに矛盾した仮定が 発生した場合に推論が停止してしまい、これを効率的に処理すること は困難である。これに対して、非単調推論は矛盾する仮定等の例外的 な事態や、状況の変化に対応できる。本研究では推論機構として非単 調推論システムのTMSを採用し、これを拡張したシステムを使用す る 注4)。

本研究では、遺跡の復元という当初から固定的にルールの適用が可 能ではない対象に、ヒューリスティックに知識を適用していくため、 TMSに対し独自の拡張を加えた。すなわち、推論の過程で矛盾が生 じた場合で、なおかつシステム内の知識でこれを解消できない場合 は、システムは新しい判断とその理由を利用者に求め、利用者が入力 した内容を新しい仮定として付け加えて行くということで推論を継続 する機能を付加した。

しかし、この拡張によってTMSの特徴である知識間の無矛盾性が 担保されなくなるため、利用者が矛盾の解決に当たってルール間の無 矛盾性を考虑する必要がある。そのため現段階のシステムでは複雑な 事例への適用は制約されるものと考えられる注5)。その場合でも復元 的考察をいくつかの段階に分割し、推論の深さを限定したステップを 重ねることで対処できると考える。

本研究の知識システムは 4 つの部分から成る

1）知識ベース

知識システムの主要部分。復元の対象となる分野に関する知識をモ デル化して記述したデータベース。システム利用の事例が増えれば成 長してくことが期待できる。

2) 事実ベース

復元対象の建築物の観察内容や平面などをモデル化して記述した
データベース。復元対象によって別個に淮備する。

3）作業ベース

復元対象に関する仮定を記述する。ここに記述された仮定を基に知 識ベース、データベースを用いて推論する。

\section{4) 推論機構}

TMSによって推論を行う推論エンジン部分。推論機構自体は汎用 のシステムを拡張したものであり、知識ベースとの組み合わせによつ て様々な復元的考察に対応することが可能である。

\section{2. 機器權成}

TMS は推論の過程を全て記憶し、その推論相互の依存関係を全て 記録するため、推論の過程で多くの記憶容量と高速な演算速度が要求 される。そのため本研究ではワークステーション上の開発環境を利用 した（ワークステーション：HITACHI9000-715-64、メモリー 64MB、HD2GB OS:HP-UX プログラミング言語: I/F Prolog)。

\section{3. 知識の獾得}

知識システムによる復元的考察のためには対象となる遺構に直接関 係するものから、考古学全般にわたるものまで広範囲の知識を獲得し なければならない。そのため知識の獲得法を検討した。知識の種類に は次のものが挙げられる。

1）考古学の共通な知識

考古学共通の知識は文献・マニュアル等の文章・図面から得られる ものが多い。本研究では考古学の発掘に関する知識、イスラーム住宅 の平面計画に関する知識を文献より抽出した（表 1)。

2) 各研究者の蓄えている知識

各研究者の蓄えている知識は一般に言語化・文書化されていないこ とが多いため、インタビュー、各研究者の問題解決作業の観察、弟子 入りなどを通じて抽出される。本研究では各研究者の蓄えている知識 の抽出を、次に述べる方法で行った。

(1) 現場におけるメモからの抽出

発掘現場で記録される様々なメモ、日誌などから、研究者の蓄え ている知識を抽出した。また発掘現場のメモとして撮影された VTR画像から知識の抽出を行った。

(2) 研究者へのインタビュー 研究者に対して発掘現場で遺跡各部のインタビューを行い、その 模様をビデオカラを用いて記録した。 これらの収集された知識を整理し、表 2 の様な知識を得た。

\section{4. 知战ベースの權策}

以上の知識をもとに知識ベースを構築した。ルールは以下の考え方 にしたがって整理し、TMSの文法によって記述した。

1) ルールの単純化

複数の条件から成り立つルールについては、それぞれの条件がOR で成立つ場合は分解して記述し、また複数の条件がANDで成立つも のは一つのルールとして記述した。

2 ) 抽象概念のルール化

知識のルール化では、具体的な知識だけではなく建物内での空間の 位置や方向などの抽象的な概念のルール化も必要となる。本研究で は、図形の読取などの抽象的な概念の判断はユーザーが行い、システ 厶はそれを前提に判断のみを行う。例えば、[もし空間がワスト・アッ ダールならば住宅の中央にある] の様に "住宅の中央”という概念 が入力されている場合、システムは入力された”住宅の中央”という 
条件を満たしているということを前提として空間がワスト・アッダー ルであるという推論を強化する。

表 3 に知識ベースに記述したルールの例を示す。

\section{5. 這構のモデル化}

知識システムでは、推論対象となる発掘された遺構を知識システム に利用できる形にモデル化する必要がある。本研究では遺構のモデル 化として、

(1) 遺構の物理的空間構成のモデル化

(2) 遺構から読みとった個々の事実のモデ化 の二つを行う。

遺構のモデル記述の手法としてフレームモデル洼6) を採用する。本 研究では知識表現の単純化のためフレームの特徵である知識の継承は 採用しない。

\section{1）遺構の物理的構成のモデル化}

遺構のモテル化にあたって、遺構中の建築的要素を空間的要素と境 界的要素にわけて考えた。遺跡を構成する空間的要素、境界的要素を フレームとし、各要素間の接続関係をリンクとしてモデル化し記述し た。

(1)空間的要素 住宅を構成する部屋、通路、中庭などであったと仮定

表1＼cjkstart文献から抽出した平面計画のルールの例

\begin{tabular}{|c|c|}
\hline 名称 & 平面計画上のルール \\
\hline $\begin{array}{l}\text { ドリーバ : } \\
\text { スキーファ : } \\
\text { ドゥッカーナ } \\
\text { ルクバ: }\end{array}$ & 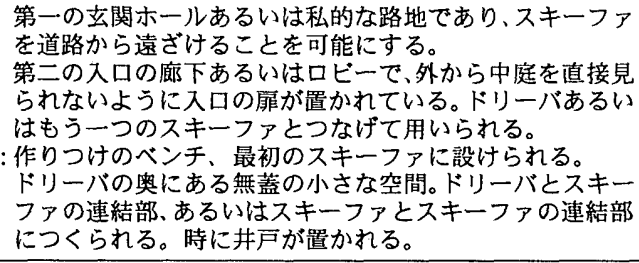 \\
\hline $\begin{array}{l}\text { ワスト・アッ } \\
\text { ブルータル : } \\
\text { ドワイリーャ }\end{array}$ & 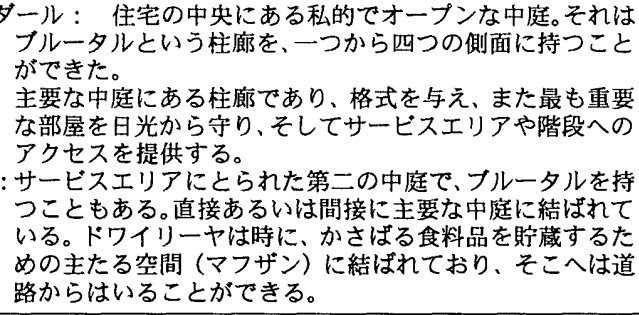 \\
\hline $\begin{array}{l}\text { バイト・ター } \\
\text { バイト・ビル }\end{array}$ & 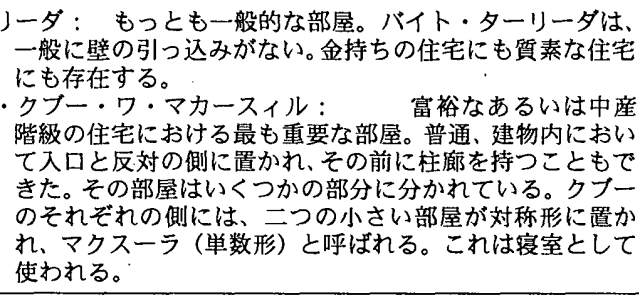 \\
\hline $\begin{array}{l}\text { マトハブ: } \\
\text { ミーハード : }\end{array}$ & $\begin{array}{l}\text { 台所。かまどが置かれている。 } \\
\text { 便所。便器がおかれている。建物のなかて下水道へ面した } \\
\text { 場所へ置かれている。近くに便槽が㯰かれている場合もあ } \\
\text { る。 }\end{array}$ \\
\hline
\end{tabular}

される部分を空間として定義する。

空間は壁、列柱、床面の段差、床面の仕上げの違いに等に着目して 領域を判断し、矩形になるように区分して記述した。矩形に分けて表 現することで、構造や面積による建筑的制約を効率よく表見すること が可能になる。

(2)境界的要素 住宅を構成する空間と空間の境界を境界的要素として 定義する。

境界には壁体、列柱、床面の段差仕上げの違いなどを含む。境界は 壁の接合部の様な複数の境界の結節点で分割して記述した。そのた め、矩形の空間であっても隣接する空間との関係で境界が四つ以上存 在する場合がある。

2）遺跡から読取った個々の事実のモテル化

観察を通じて遺構から読取った個々の事実をモデル化し記述した。 例）建築的付属物（かまど、水周り、作り付けの棚等）の痕跡、出土 遺物、境界の構造、材料、色、表面的な文様などの特徵、開口部の有 無など。

\section{表 2 収集した専門家固有の知識の例}

\begin{tabular}{|c|}
\hline 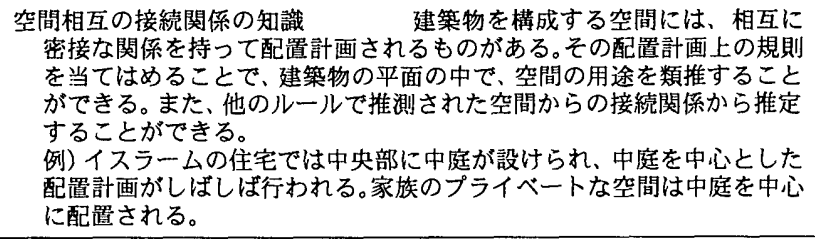 \\
\hline 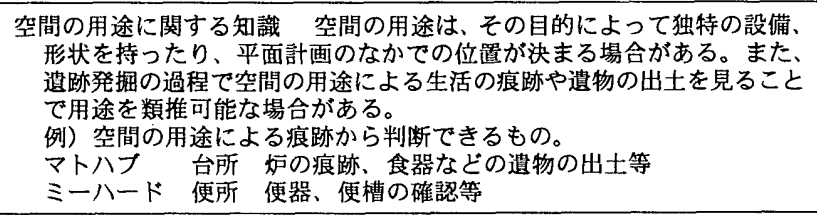 \\
\hline 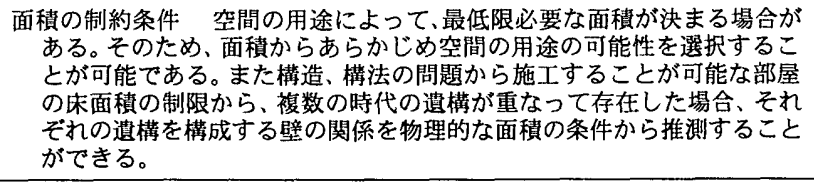 \\
\hline 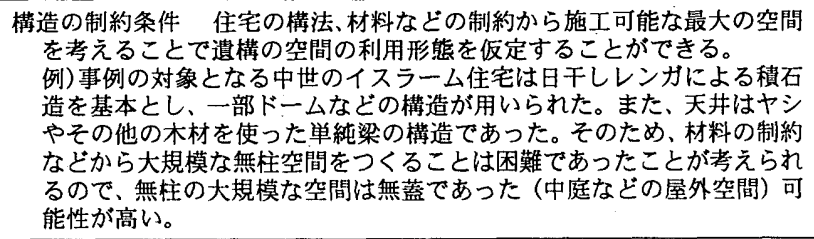 \\
\hline $\begin{array}{l}\text { 開口部の位置などの知識 空間に付随する開口部の位置、大きさ、種類な } \\
\text { どからそ利用目的が推定される場合もある。 } \\
\text { 例) 外部に向かって開いた開口部をもつ空間 } \\
\text { 玄関ホールであった可能性がある。 }\end{array}$ \\
\hline 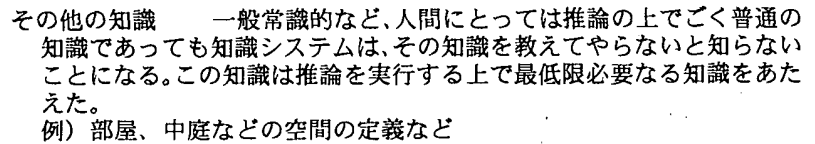 \\
\hline
\end{tabular}

表 3 知識ペースに記述したルールの例

\begin{tabular}{|c|c|c|}
\hline 抽出された知識 & 単純化したルール & 知識ベースに記述したルール \\
\hline $\begin{array}{l}\text { ワスト・アッダール : } \\
\text { 住宅の中央にある私的でオープンな } \\
\text { 中庭。それはブルータルという柱廊 } \\
\text { をつから } 1 \text { つの側面に持つことが } \\
\text { できた。 }\end{array}$ & $\begin{array}{l}\text { 1）もし空間がワスト・アッダー } \\
\text { ルなら住宅の中央にある。 } \\
\text { 2）もし空間がワスト・アッダー } \\
\text { ルなら中庭である。 } \\
\text { 3）もし空間がブルータルである } \\
\text { ならばワトアッダールと接 } \\
\text { している。 }\end{array}$ & 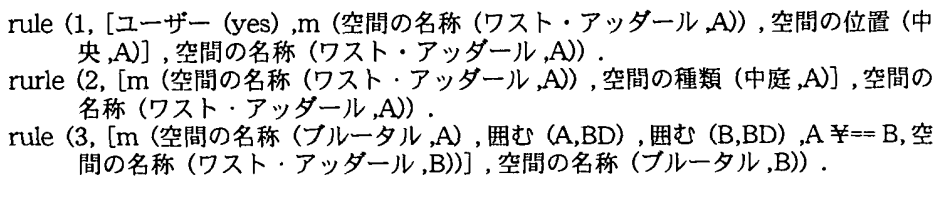 \\
\hline
\end{tabular}


図 1 に示す椺棈の記述モデルの一部を表 4 に示す。

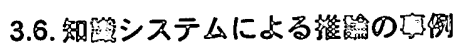

知識システムの適用事例として図 2 に示す平面を対象としてケース スタティーを行った。住宅をモテル化したものが図 3である (以降便 宜上、住宅を柱成する各領域に番号をつけ空間1-空間20 と呼ぶ)。こ こでは空間7に関する推論の過程を追跡して本システムでの推論の事 例を示す。

1）空間の仮定

ケーススタティーの住宅に対して、推論を始めるための基筑とし て、各空間について次のように仮定した。

仮定 1 空間 7 をドワイリーヤであると仮定する。

仮定 2 空間 7 をワスト・アッダールであると仮定する。

仮定 3 空間 2,11,15 をバイト・ターリーダであると仮定する。

仮定 4 空間 9 をバイト・ビル・クブー・ワ・マカースィルであると 仮定する。

仮定 5 空間 1 をドリーバであると仮定する。 仮定 6 空間 3 をスキーファであると仮定する。 仮定 7 空間 13 をミーハードであると仮定する。 仮定 8 空間 16,17 をマトハブであると仮定する。 仮定 9 空間 10 がブルータルであると仮定する。

ここでは仮定 1 と仮定 2 が互いに矛盾している。この矛盾する仮定 に対して推論を行い、復元的考察の支援を行う。

2）空間 7 をドワイリーヤと仮定しての推論

(1) [空間 7 がドワイリーヤである] という仮定をシステムに与え るとルールベースが適用され、そのときの各空間の関係が検証 される。

・空間7がドワイリーヤであるとすると空間7はサービスエ リアである。

・空間 $2,11,15$ がバイト・ターリーダであるとするとプライ ベートな部屋である。

(2)專実ベースに記述した空間モデルから次の事実が検証される。

。空間 7 と空間 $2,11,15$ が接続している。

(3)このとき仮定 $3 に$ 関して、[サーピスエリアは直接プライベート な部屋には接続しない] というルールに矛盾が発生する。

。空間 7 と空間 $2,11,15$ の接続は矛盾している。

(4)この矛盾を解決するため矛盾解消機構が起動して矛盾を導く記 述をたどり、仮定が否定される。

・空間 7 をドワイリーヤとする仮定を o u t $\mathrm{t}^{\text {注 }}$ ににする

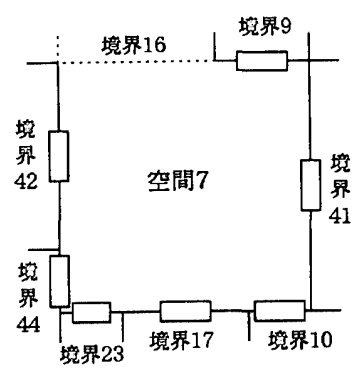

空間 7 フレーム

面穞 $6.12 \times 6.12$

空間の種穎 : 中庭

境界 $16,9, \cdots$

界 9フレーム

種類 : 壁体

開口部がある

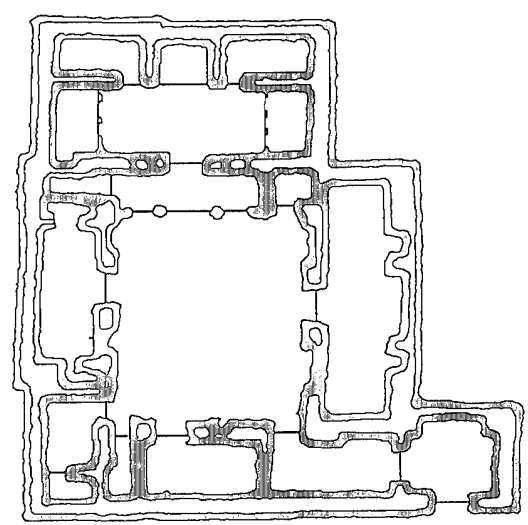

図 2 ケーススタディの住宅の平面注7

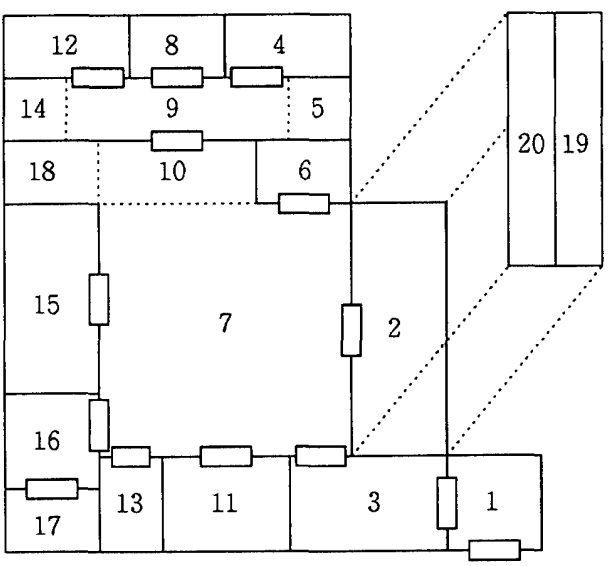

図 3 モデル化した住宅の平面

表 4 邀棈の記述モデルの例

\begin{tabular}{|c|c|c|c|}
\hline 事実 & & 記述モデル & 内部表現 \\
\hline $\begin{array}{c}\text { 空間 } 7 \text { は縮横 } 6.12 \mathrm{~m} \text { 空間である。 } \\
\text { 空間 } 7 \text { は中庭であると仮定する。 } \\
\text { 空間 } 7 \text { は境界 } 16,9,41,10,17,23,44,42 \text { で } \\
\text { 用まれた空間である。 } \\
\text { 境界 } 16 \text { は列柱である。 } \\
\text { 境界 } 9 \text { は壁で開口部がある。 } \\
\text { 境界 } 10 \text { は壁で開口部がある。 } \\
\vdots \\
\vdots\end{array}$ & $\begin{array}{l}\text { 境界 } 16 \\
\text { 境界 } 9 \\
\text { 境界 } 41 \\
\text { 境界 } 10\end{array}$ & $\begin{array}{l}\text { 空間の種穎 : 中庭 (仮定) } \\
\text { 面積 : } 6.12 \mathrm{~m} \times 6.12 \mathrm{~m} \\
\text { 境界 : } \\
16,9,41,10,17,23,44,42 \\
\text { 境界分類 : 列柱 } \\
\text { 境界分類 : 壁 } \\
\text { 境界条件 : 開口部あり } \\
\text { 境界分穎 : 壁 } \\
\text { 境界条件 : 開口部あり } \\
\text { 境界分穎 : 壁 } \\
\text { 境界条件 : 開口部あり } \\
\quad \vdots\end{array}$ & 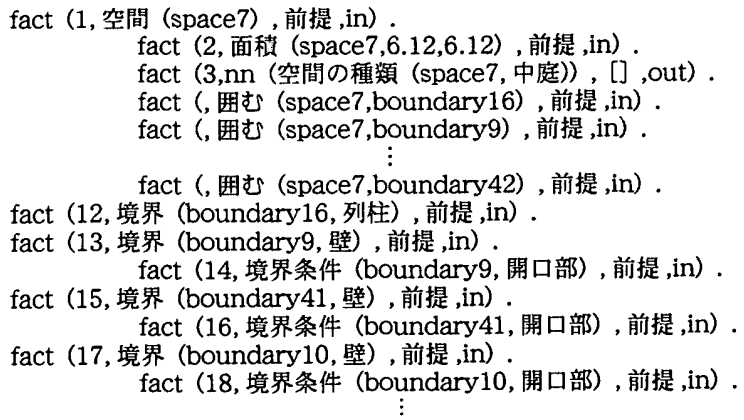 \\
\hline
\end{tabular}




\begin{tabular}{lrlll}
\hline ルール6 & & & & \\
を適用 & & & \\
新主張 & $314:$ & 矛盾 (問題配置 (space7,space2)) & を追加 \\
新主張 & $315:$ & 矛盾 (問題配置 (space7,space11)) を追加
\end{tabular}

\section{矛盾解消開始}

リターンキーを押してください

事実 314：問題配置（space7,space2） に矛盾発見

新事実 353 : nogood (314) を追加

事実 292 : 空間の名称（ドワイリーヤ,space7）をｉ nからou tに変えました

事実 293 : 空間の種類（サービス,space7）を i nからou t に変えました

事実 301 : 問題配置 (space7,space2) を i nから o u t に変えました

事実 314 : 矛盾 (問題配置 (space7,space2)) をi nからo u t に変えました

事実 $20: \mathrm{nn}$ (空間の名称（ドワイリーヤ,space7)）に理由付け [根拠，[353]] を与えました ... (5)

i $\mathrm{n}-\mathrm{out}$ 值は in です

事実 315：問題配置（space7,space11）に矛盾発見

新事実 354 ： nogood (315) を追加

事実 292 : 空間の名称（ドワイリーヤ,space7） をi nからou t に変えました

事実 293 : 空間の種類（サービス,space7） を i nからou t に変えました

事実 302 : 問題配置 (space7,space11) をi nからou t に変えました

事実 315 : 矛盾（問題配置（space7,space11）） を i nからo u t に変えました

事実 $21: \mathrm{nn}$ (空間の名称（ドワイリーヤ,space7)）に理由付け [根拠，[353,354]] を与えました ... (6)

i $\mathrm{n}-\mathrm{out}$ 值は in です
(1)ルールの適用 ルールの適用 によって空間 7 (ドワイリー ヤと仮定)を中心とした接続 に矛盾が生じる。

(2)矛盾の解消 空間 2 に関して (1)の矛盾が根拠として記述さ れ矛盾解消が作動する。

(3)仮定の否定 矛盾のもとと なった仮定が検索され、否定 される。さらに矛盾のもとと なった記述を理由とする記述 が否定される。

(4)矛盾の否定 矛盾を引起した 仮定が否定されたことで、矛 盾が否定される。

(5)否定の根拠の提示 矛盾を引 起した仮定に(2)で記述された 根拠が付加される。

(6) 空間 11 に関しても(2)〜(5)の 操作が絽返され否定の根拋が 提示される。
(5)空間7をドワイリーヤとする仮定を理由付にしていた推論が否 定される。

・空間 7 がサービスエリアであるとする記述が否定される。

(6)矛盾の原因となった仮定が否定されたことで矛盾が否定され る。

- 空間 7 と空間 $2,11,15$ の接続が矛盾しているという矛盾が 否定される。

(7)空間 7 がドワイリーヤであることが否定される。

空間7がドワイリーヤであるとする仮定の矛盾解消の推論遂行過程 の一部を表 5 に示す。

3）空間 7 をワスト・アッダールと仮定しての推論

先の推論で[空間 7 をドワイリーヤであると仮定する]が否定され たので対立する仮定の [空間 7 をワスト・アッダールであると仮定す る]をシステムに入力して同様に推論を行う。

(1) [空間 7 がワスト・アッダールである] という仮定をシステム

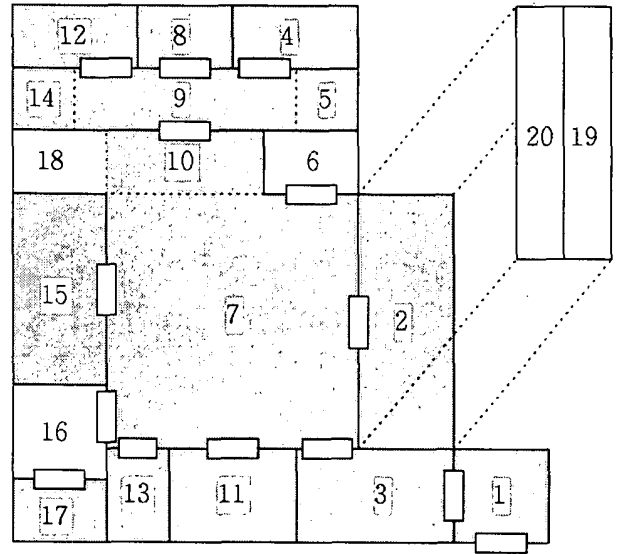

図 4 システムによる推論の結果
に与えるとルールベースが適用され、空間 7 がワスト・アッ ダールであると仮定したときの各空間との関係が検証される。 このとき仮定に対して矛盾が生じなかった。

(2)空間 7 がワスト・アッダールであることが推定される。

・空間7がワスト・アッダールであったとする仮定に矛盾が 生じないことが提示される。

2)、3）に示す推論の過程で得られた結果は、たとえそれが否定さ れても、否定の根拠とともに作業ベースに記述され保存される。この 否定された記述は、新たな仮定や事実、ルールを加えて推論が実行さ れたときに別の結論を導く場合がある。また理論的にも、無矛盾な複 数の遺構復元の解が得られることが考えられる。こうした場合も、新 たな仮定や事実、ルールをを加えることで更なる推論を実行すること ができる。

このような作業で仮定に関して矛盾のない組み合せを有する遺構の

表 6 推定された部屋のリスト

\begin{tabular}{llll}
\hline 種類 & 呼称 & 空間 & 推論の妥当性 \\
\hline 中庭 & フルルータル & space10 & $\bigcirc$ \\
& ワスト・アッダール & space7 & $\bigcirc$ \\
\hline 部屋 & バイト・ビル・クブー & space4 & $\bigcirc$ \\
& ワ・マカースィル & space5 & $\bigcirc$ \\
& & space8 & $\bigcirc$ \\
& space9 & $\bigcirc$ \\
& space12 & $\bigcirc$ \\
& space14 & $\bigcirc$ \\
& スキーバ & space1 & $\bigcirc$ \\
& バイト・ターリーダ & space3 & $\bigcirc$ \\
& space2 & $\bigcirc$ \\
& space11 & $\bigcirc$ \\
& space15 & $\bigcirc$ \\
& マトハード & space13 & $?$ \\
& & & $?$ \\
\hline
\end{tabular}

空間19、20はこの住宅の平面に属する空間ではないと推定される 推論の妥当性の凡例: 0 推論の結果が妥当である、 $\times$ 推論の結果が妥当で はない、? 妥当性の検証ができなかった 
空間構成を得ることができる。この例の場合、推論の結果、20 室中 15 室が推定され、空間 19,20 の存在が否定された（図4、表 6)。残 りの 3 室は事実あるいは知識が不足しているため不明であった。

事例では26のルールをもつルールベースでの推論の結果、推論の 終了までのステップ数は 335 であった。

なお、この結果について考古学の專門家に検証を依頼したところ、 表 $6 に$ 示す判定を得た。システムの推論した空間のうち空間 13 と空 間 17 をのぞく推論が妥当であるとの結果である。また空間 13 と空 間 17 の推論に関しては、妥当性を判断するには事実が足りないとの 結果で、推論そのものの否定ではなかった。

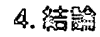

復元的考察という非常に多くの要因を考虑しながらヒューリス ティックに行われる推論過程を支援するシステムを䊗筑し、試験的に イスラム住宅の平面構成の復元について検討した。

住宅の平面図のみを初期条件として、各部屋の用途が全く分からな いという段階から試行錯誤を繰り返し、20室中 15 室の用途を判別、 2室の存在を否定することができた。このことから、知識システムを 使って空間構造 (空間利用)を復元する過程を支援する試みは初期の 目的を達したと考える。

また、システムに記述した知識の表現方法が推論に有効であり、復 元的考察の知識を蓄葐し外在化する見通しが得られた。

試行は単純な事例であり、特にシステムを使わなくても判別できな いことは無い。しかし、システムを利用したことで(1)何を論拠に判定 したのかを明示していること、(2)作業過程で設定した仮定に論理矛盾 があると的確に指摘してくれることなどは、研究者の思考を整理する 道具しての有効性を提示したと言えよう。

今後の㹎題としては、推論機棈の問題があげられる。非単調推論で も推論の基本となる知識ベースに記述されたルール間の矛盾のチェッ クは対応できない。そのため知識システムの記述内容によっては無限 ループが発生する可能性がある。この問題に対しては研究者が矛盾の 無いルールを作成することで対応するしか現状では方法が無い。この 点に関してはさらに上位のルールの構筑もしくは、ルール間の馨合性 のチェックが必要であり今後の課題と考えられる。

また、復元的考察は、知識量と、知識を的確に検索して適用する能 力が問われるわけであるが、豊富な経験を持つ研究者の知識、特に常 識をシステムに組み込むことで、初学者の教育勏果という意味でも大 きな力を発揮すると期待できる。

本研究で提案した知識システムの応用䇥囲は、今回の様な平面計画 の分析から構造や形態の復元作業支援まで広い箄囲での適用が期待で きるものであり、様々な問題への応用を考えている。
钊辞

本研究を進めるにあたり、財) 中近東文化センター 川睦夫主任研究員には 推論結果の検討を含めて贵重な助言、協力をいただきました、ここに記して謝 意を表します。

本研究はH 7 年度文部省科学研究费 試㖵研究 (B) (1)「推論橙構を持つ邀跡 復元作業支援 3 次元シミュレータの開発」（禗題番号 05555101 研究代表 能 本大学教授 両角光男) の一環として実施した

家饬立旅

1) 文化庁文化財保護部 : 埋藏文化財発掘調㚗の手引き，財団法人国土地理協 会, 平成元年

2) ベシーム・S・八キーム著，佐藤次高監訳 : イスラーム都市アラプのまち ブくりの原理, 第三書館, 1990.12

3) 高野 真: Prolog で学ぶAI手法推論システムと自然言語処理, 敬学出版株 式会社, 1988

4) 寺野隆雄：知識システム開発方法論，朝倉書店，1993.4

5) マービンミンスキー他著，佐伯胖螎：認知科学の基底，産業図書，1986

の) 堅田直:情報考古学 パソコンが描く古代の姿, ジャストシステム, 1996.4

7) 位笴和久, 両角光男 : 遗跡の空間構成推論システムに関する研究, 日本建 築学会・情報システム技術委員会 第 12 回情報システム利用技術シンボ 沛ウム論文集, pp.187〜 pp.192，1989.12

8) 中村裕文, 両角光男, 位奇和久: 造跡復元の過程を支援する推論システム の開発 推論機榜を持つ造跡復元支援 3 次元シミュレータの開発, 日本建 築学会中国。九州支部研究報告第 10 号, pp.705 pp.708, 1996.3

9) 中村裕文，両角光男，位寄和久：迎跡の復元過程を支援する推論システム の開発，日本建筑学会大会学術讙演梗概焦 (近畿), pp.385 pp.386, 1996.9

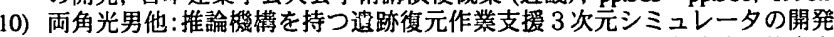
平成 7 年度科学研究費補助金 試碎研究 (B) (1) 研究成果報告書, 熊本大 学, 1996.3

注

例えば、西和夫・小沢朝江「二条城二の丸御殿の大広間等諸御殿の得 元研究一建筑と障壁画の総合的検討一」日本建築学会計画系論文焦、第 492 号 1997 年 2 月では部材に残された改築の際の加工の痕跡や座教飾り などの現位置の推定から復元的考察が行われている。

注 2）本論文ではユーザーによってたてられた仮説を仮定、システムによっ て、あるいはユーザーによって仮説を立てて推論を行った結果得られた答 を推定と呼ぶ。

注 3）知識システムとは、対像領域に関する知識を陽に問題解決に利用した コンピュータシステムを音哧する。知䜟システム结，通常人間の知性を用 いなければ解けないような問題を解決するのに、専門家の経験的知識 （ヒューリスティクスや、その他の知識をコンピュータへ組み込んて、人 間に代わってあるいは人間をたすけて問題解決を行うことを目的としたコ ンピュータシステムのことを指し、一般に言われるエキスパートシステム の上位概念にあたる。

注 4) TMSはドイルによって提案された非単調推論システムである。TMS ではシステムの外から新しく自分自身の一部を否定する記述が入ってきた とき、矛盾を倠く記述（既に内部に記述されていて新たに否定された命題 と、その否定を引き起こしたシステムの外から入ってきた伤題)のうちい ずれかが無効にされる。内部の記述が無勃にされた場合、その記述から望 かれた仮定的事実も無効にされる。そのためには、システムの中の主張問 の传存関係はすへて記述されている。また仮定的事実が何を根拠としてい るかが記管されている必要がある。さらに、後に本当は外部から入ってき た主張が誤っていたことが判ったときには、否定された記述は復元され る

注 5) 個人の能力で対応できる複雑度は不明であるが、今後の試行により釱 討を重ねて行く予定である。

注 6) フレームモデルは人間が一度に想起あるいはあるいは、連想する情㥂 や概念間の相互の関係をひとまとめに表す方法である。

注 7) ベシーム・S・八キーム著, 佐藤次高監訳 : イスラーム都市アラプの まちづくりの原理，第三書館，1990.12，pp.113，ルヴォールによって分 類されたチュニス・メディナの 4 つの家の型より引用。

注 8）TMSで用いられる用語で、仮定された"事実"（TMSでの記述）の状 態を表す。

in (イン): 真であると信ずるに值する根拋がある out (アウト): 真であるという根拋がない nogood : 矛盾が発生している

（1997年 3 月10日原稿受理，1997年10月17日採用決定） 